IZA DP No. 8476

Private Education Market, Information on Test Scores and Tuition Practices

Sergio Firpo

Vladimir Pinheiro Ponczek

Vítor Augusto Possebom

September 2014 


\title{
Private Education Market, Information on Test Scores and Tuition Practices
}

\author{
Sergio Firpo \\ Sao Paulo School of Economics, FGV \\ and IZA \\ Vladimir Pinheiro Ponczek \\ Sao Paulo School of Economics, FGV \\ Vítor Augusto Possebom \\ Sao Paulo School of Economics, FGV
}

Discussion Paper No. 8476
September 2014

IZA

P.O. Box 7240

53072 Bonn

Germany

Phone: +49-228-3894-0

Fax: +49-228-3894-180

E-mail: iza@iza.org

Any opinions expressed here are those of the author(s) and not those of IZA. Research published in this series may include views on policy, but the institute itself takes no institutional policy positions. The IZA research network is committed to the IZA Guiding Principles of Research Integrity.

The Institute for the Study of Labor (IZA) in Bonn is a local and virtual international research center and a place of communication between science, politics and business. IZA is an independent nonprofit organization supported by Deutsche Post Foundation. The center is associated with the University of Bonn and offers a stimulating research environment through its international network, workshops and conferences, data service, project support, research visits and doctoral program. IZA engages in (i) original and internationally competitive research in all fields of labor economics, (ii) development of policy concepts, and (iii) dissemination of research results and concepts to the interested public.

IZA Discussion Papers often represent preliminary work and are circulated to encourage discussion. Citation of such a paper should account for its provisional character. A revised version may be available directly from the author. 


\section{ABSTRACT \\ Private Education Market, Information on Test Scores and Tuition Practices}

In this paper, we study the impact of disclosing information about school quality of private schools in Brazil on school choice. Particularly, we investigate whether test score disclosure affected private schools' tuition prices. In 2006, Brazil started to announce the schools' average test score of ENEM, a high school exit exam run by the federal government. Using longitudinal school data, we gauge the effect of test score disclosure on tuitions of private schools for three different schools levels (elementary, middle and high school). We find that the disclosure of schools' average test scores affects tuitions positively for all these three educational levels, but the effect is larger for high school tuitions. We also find that private education markets are local instead of national, since local ranks better predict tuition prices than national ranks. Finally, adjustments on prices did not follow immediately after the publication of scores but occurred gradually over time, revealing that the parents needed some time to trustfully associate results on the exam to new information on school quality.

JEL Classification: $\quad$ O12, I21, L15, D82

Keywords: educational markets, information provision, private schools, tuition practices, school quality

Corresponding author:

Sergio Firpo

Escola de Economia de São Paulo - FGV-SP

R. Itapeva, 474/1215

São Paulo - SP

Brasil, 01332-000

E-mail: sergio.firpo@fgv.br

\footnotetext{
* We thank the Instituto Brasileiro de Economia (IBRE) and the National Institute of Educational Studies and Research (INEP) for providing valuable data and information. The authors are grateful to the Sao Paulo School of Economics for research support and Conselho Nacional de Desenvolvimento Científico e Tecnológico (CNPq) for research funding. Usual disclaimer applies.
} 


\section{$1 \quad$ Introduction}

The literature that studies the impact of hard and soft school accountability systems on students', parents', teachers' and principals' behaviors is vast. ${ }^{1}$ Many studies have focused on the relation between school standardized tests and school choice as a way to come up with measures of willingness to pay for school quality. Most of the school systems that have been studied are in general public. Thus, those studies can only offer indirect measures of willingness to pay for school quality. Housing prices have been typically used as providing the monetary measure between school quality and willingness to pay. For school systems that link the place of residence to school enrollments, Black (1999), Figlio \& Lucas (2004), and Fack \& Grenet (2010) provided evidence that that school test score reports do affect housing prices. In fact, in the urban and housing economics literatures it is well documented the link between school attributes and housing prices. ${ }^{2}$ However, housing prices are affected by many other observable and unobservable factors beyond neighborhood's school quality and a more direct price, such as tuition, would have been more appropriate to measure how much parents value school quality.

Clearly, even if information on tuition were readily available, noiseless measures of school quality are either rare or difficult to be processed by parents. Hastings et al. (2007) show that in the U.S., parents tend to choose high-quality public schools after receiving simplified information about school quality. Koning \& van der Wiel (2010) analyze the impact of public schools external evaluations on enrollment decisions in the Netherlands. They find that a positive evaluation increases the inflow of students in the year after the publication and that the probability of a student' choice for a specific school is positively and significantly affected by its quality score.

For developing countries, there are some recent pieces of evidence of the relationship between information on school quality and parental choice. Andrabi et al. (2014) study the effects of distributing test score information (report cards) to Pakistani parents using randomized control trials (villages are the randomization unit). They find that additional information on school quality affects positively student learning in low performing schools in both private and public sectors. Moreover, they find that tuition fees decreased after information on quality

\footnotetext{
${ }^{1}$ See Figlio and Loeb (2011) for a comprehensive survey.

${ }^{2}$ See, for example, Haurin \& Brasington (1996); Brasington, (1999); Downes \& Zabel (2002); Gibbons \& Machin (2003 and 2008); Kane, Riegg \&Staiger (2006); Davidoff \& Leigh (2008); and Clapp, Nanda \& Ross (2008).
} 
was released for high performing private schools. This latter result can be rationalized with high quality private schools already providing costly signals of their quality and extracting informational rents before the publication. Camargo et al. (2014) exploit a discontinuity on the rule of test scores publication and find the same positive effects on learning from low performing schools, but only for the private sector in Brazil. They interpret their results as evidence of the effectiveness of market incentives that schools in the private sector face. However, Camargo et al. (2014) do not exploit the impact of score publication on prices as they do not have data on tuition fees. Mizala \& Urquiola (2013) quantify the impact on number of enrollments, number of classrooms, tuition prices and socioeconomic composition of providing schools with a quality seal in Chile. They found that informing parents about schools' effectiveness has no effect on market outcomes through school competition, a surprising and unexpected result according to them.

This paper contributes to the literature on the willingness to pay for school quality by analyzing the impact that a recent change in the policy regarding disclosure of schools' average test scores had on tuition practices of Brazilian private schools. Unlike developed countries, private schools in Brazil are not only elite ones, but also correspond to about $20 \%$ of enrolments in the basic education. We use a unique longitudinal dataset of Brazilian private schools to measure the impact of that policy change. More specifically, we study the impact of the unanticipated disclosure of the National Secondary Education Exam (ENEM) test in Brazil on tuitions of private schools. Therefore, unlike most of the literature that relies on housing prices, we use tuition fees, which are a more direct measure of willingness to pay for school quality.

Since 1998, Brazilian Ministry of Education has kept all individual scores anonymous, but, starting with ENEM 2005, averages by school were made public. ${ }^{3}$ We had access to individually, student-level, anonymized ENEM results with a link to their schools. Therefore, we were able to construct school test scores for ENEM editions previous to 2005. We matched that data with the micro data from IGP (Índice Geral de Preços), one of the most

\footnotetext{
${ }^{3}$ That part of our dataset has also been used by Camargo et al. (2014). In fact, ENEM was only made public for schools that had at least ten students taking the exam. Camargo et al. (2014) exploit this discontinuity to check how students and school managers reacted to the new piece of information. In our sample, however, as it will be discussed later, we only have schools with publicized scores as we merged that dataset with the one containing information on tuition, which is systematically collected only for large schools.
} 
used consumer prices indexes in Brazil. IGP is constructed by Fundação Getulio Vargas and regularly collects data on several educational items, in particular, school tuition fees.

Our identification strategy compares how tuitions correlate with ENEM scores before and after the disclosure of those scores. Therefore, we pool observations from 2004 to 2009 and run school ordinary least squares (OLS) and fixed effect regressions of schools' tuitions on schools' ENEM scores and the interaction of the score with a dummy variable for years after the score disclosure. The idea is that even before the disclosure, students and parents received noisy signals of school quality, which were partially correlated to the undisclosed ENEM scores. That correlation can be explained in part by unobservable (to the econometrician) time-invariant heterogeneity, such as school reputation, and that is why fixed effect regressions are important. After the disclosure, parents and students receive a better signal and their reaction is potentially more correlated to the average scores (or school rankings based on the test scores). Therefore, if information on average school scores provides indeed extra information about school quality, one would expect that the correlation between tuitions and test scores would become stronger after the release of average test scores that began in 2006 .

Our results indicate that the disclosure affected schools' tuitions and that the correlation between average test scores and tuitions became more positive after that event. OLS and fixed effects estimates differ substantially, and results point that pricing before ENEM release was mostly related to unobservable time-invariant school characteristics. Moreover, we show that the impact of the publication of test scores on tuitions depended more on how the school performed locally and not nationally and also that it was not immediate, i.e., it took some time until the prices reacted to the new piece of information received. Finally, as we have data on tuitions per grade, we show that even for lower grades of primary schools prices changed after ENEM release. The results are robust to several checks.

Unlike Andrabi et al. (2014) we did not study the differential effects of score publication on tuition by initial school quality level. In fact, we did not investigate further the existence of heterogeneous effects due to the relatively low number of schools for which data on tuition was available. It is nevertheless plausible that, at least qualitatively, results reported in Andrabi et al. (2014) on information affecting negatively tuition prices of high quality schools could also have been found in the Brazilian case. Such investigation would nevertheless require usage of alternative datasets. 
Our paper reports some results that differ from those in Mizala \& Urquiola (2013). In particular, they found no effect of additional information on tuition practices. Their setup differs from ours because, unlike our paper, they investigate the net effects on schools of an award/quality seal, controlling for the score used to assign the award. In our case, we measure the impact on tuitions of releasing to the public the school average ENEM scores -a continuous measure-, controlling for school reputation. Average scores became public for all schools and at the same time, and schools were not grouped according to the score results. Therefore we do not have a clear treatment vs. control setup as in Mizala \& Urquiola (2013).

Our study found statistically significant and robust results about ENEM school ranks' impact on tuition prices, even though they might be considered economically small according to an individual perspective. Koning \& van der Wiel (2010) faced a similar problem, also finding statistically significant and robust, but economically small results about school ranks impact on kids' willingness-to-travel.

An important difference between this work's results and the results found by Figlio \& Lucas (2004) is that while the latter concluded that school rankings' impact on the residential market got weaker with time due to the fact that the signals given by school rankings were noisy, we found that evidence that the impact of school rankings on the Brazilian private education market got stronger at least for the three years immediately after the publication of ENEM. We conjecture that parents gradually started taking ENEM results as credible signals of school quality, strengthening the relation between information and tuitions.

The paper proceeds as follows. Next section discusses the institutional background of the ENEM exam and the private school market in Brazil. Section 3 describes the datasets and presents descriptive statistics of the data. Section 4 shows the empirical strategy. The results are discussed on section 5. Section 6 concludes.

\section{Institutional Description}

Brazilian institutional settings present an interesting case to study the relationship between information on school and tuition fees. First, private schools represent an important share of 
enrollments. In 2012, 16.46\% of all Brazilian high school students were enrolled in a private school. $^{4}$

Secondly, ENEM, which was created in 1998, is a national and standardized test whose main goal is to evaluate high school students' proficiency. ENEM is a non-mandatory exam organized by the National Institute of Educational Studies and Research (INEP), which is part of the Brazilian Ministry of Education (MEC). Even though ENEM is a voluntary exam, many students take it, because it is frequently used as one way to get into college or to get a government scholarship. This makes ENEM a high-stake test, indicating that students will dedicate efforts to get a good score. Only students enrolled in the last grade of high school (high school year 3), and students who have already finished it can take that exam. ENEM consists of two parts: one test of multiple-choice questions covering four different subjects and an essay. Since 2008, its scores have been determined using Item Response Theory.

Thirdly, on 2006, Brazilian Educational Ministry decided to make public ENEM 2005's school average scores. This was an unexpected and exogenous institutional change that is likely to have increased the demand for high quality schools and decreased the demand for low quality schools according to ENEM average scores. ${ }^{5}$ For this reason, a change in the partial correlation between ENEM average scores and tuition prices before and after this exogenous institutional decision is likely to have happened due to additional information on school quality. Moreover, this policy was continued in the following years, making possible to verify if this change becomes increasingly stronger after private agents got more information about this policy.

Since 2006, annual school average ENEM scores have been available at the INEP's website and have been used by the media in the production of local, regional, and national school rankings. Despite the fact that there is no hard accountability system based on school average ENEM scores, managers, teachers, parents, and students care about their schools' average ENEM scores. Camargo et al. (2014) report that schools advertise their own ENEM results and that some real estate agencies inform the average ENEM score of the schools near a given

\footnotetext{
${ }^{4}$ This number is even higher in some states. In 2012, for Rio de Janeiro and Distrito Federal, respectively, $21.43 \%$ and $25.48 \%$ of all high school students were enrolled at private schools.

${ }^{5}$ Given that the release was not anticipated, schools could not respond by gaming the system through student selection, teaching-to-test activities, or in any other way.
} 
location. According to them there is ample evidence of the large media attention that ENEM average scores by school have received since their first publication.

We believe it is important to make two more comments concerning (i) the division between elementary school, middle school and high school and (ii) the reason why we employed only $2^{\text {nd }}$ year of elementary school, $1^{\text {st }}$ year of middle school and $3^{\text {rd }}$ year of high school tuition prices instead of all the possible tuition prices.

In Brazil, the basic education system is divided into 12 grades. Kids start elementary school (grades 1 to 5) when they are 6 years-old if they were born in the first semester of the year and when they are 7 years-old if they were born in the second semester. Elementary school lasts five years and, after that, kids enter middle school (grades 6 to 9), which lasts four years. The end of basic education is high school (grades 10 to 12), which lasts three years, and teenagers that had no grade retention graduate when they were between 17 years-old or 18 years-old.

Using high school year 3 (grade 12) tuition prices to verify the impact of disclosure of ENEM scores on the demand curve for private schools was an obvious choice, because, in the last year of high school, parents and teenagers are more concerned about standardized tests, getting into college and getting a government scholarship. As a consequence, they are likely to respond more strongly to school ranks. However, it is also expected that parents respond to ENEM school ranks not only when they decide to enroll their children at high school, but also when they decide to enroll their children at elementary and/or middle schools.

Therefore, we also use middle school year 1 (grade 6) tuition prices. Also, note that it is more frequent to observe parents enrolling their kids at new schools at the beginning of a cycle ('elementary', 'middle', 'high') than during a cycle. Finally, most schools charge only one tuition price per cycle, implying that tuitions prices for intermediate years within a given cycle are the same, for example.

For elementary school, the same reasoning would imply that we should have used the $1^{\text {st }}$ year of elementary school and not the $2^{\text {nd }}$ one (grade 2). However, there was a recent institutional change and elementary education changed from 4 to 5 years. Since not all schools at the 
period 2004-2009 had already adopted the 5 year curriculum, we decided to use elementary school year 2, which was previously the admission year.

Schools are free to decide on prices, but not entirely. There is a list of restrictions imposed by Brazilian law concerning tuition price regulation. ${ }^{6}$ The most important are: (i) tuition for the entire year $t$ must be set on year $t$-1; (ii) tuition prices increases must be justified according to cost increases; (iii) year $t$ tuition prices cannot change during year $t$. The second restriction limits upward changes on prices.

Given the lack of institutional flexibility to adjust prices upward, it is expected that an increase in the partial correlation between ENEM school average scores and tuition prices after the 2006 institutional change, is mostly due to the low quality schools reducing (or increasing less) their tuition prices. Therefore, our results can be seen as a lower bound of the true impact of school quality on tuition.

\section{Data Sets and Descriptive Analysis}

In order to answer the questions whether ENEM scores publication impacts on private schools' tuition structure, two data sets will be used.

Tuitions come from a sample of private schools surveyed by Instituto Brasileiro de Economia (IBRE) of Fundação Getulio Vargas. The dataset includes annual information on elementary school year 2, middle school year 1 and high school year 3 tuition nominal values for nine cities for the period between 2006 and 2009. ${ }^{7}$ Nominal values were deflated and we present values as of Reais of January 2006. This data set presents an unbalanced panel structure. The number of schools in the sample ranges from 263 to 342 from 2006 to 2009. It represents a small subgroup of the universe of private schools in Brazil. In 2006, there were around 35,000 private schools in the entire country.

We also used the data on ENEM scores. The Brazilian Ministry of education organizes, through INEP, a national standardized test in Brazil called ENEM (High School National

\footnotetext{
${ }^{6}$ Law 9,870/99

${ }^{7}$ The cities are: Belo Horizonte, Brasília, Guará, Porto Alegre, Recife, Rio de Janeiro, Salvador, São Paulo and Taguatinga. First year of data availability is 2006 .
} 
Exam). Students take this test voluntarily, but its importance increased due to the fact that more flagship universities are considering ENEM scores in their application process. The data set includes students' results since 1998, and we used student-level data to construct school average scores from 2004 to 2007. Since 2006, starting with ENEM 2005, school average results have been made public to the general society only in $2006{ }^{8}$

The exogenous institutional change on publication of school performance also explains why ENEM data set starts in 2004 and ends in 2007 while IBRE's data set starts in 2006 and ends in 2009: when parents decide, in the second semester of year $t$, to enroll their children at school for year $t+1$, they face school's tuition of $t+1$. However, updated information on ENEM is that of year $t-1$ ENEM scores, because Ministry of Education publishes year $t$ ENEM results in the middle of year $t+1$.

We used the school name in order to match them in both dataset. We were able to match around $66 \%$ of schools only. However, there is no significant difference in tuition's price between matched and unmatched schools.

As Table 1 shows, there was a real price increase in high school tuitions, suggesting that recent changes in the Brazilian economy, e.g. income increase and better income distribution, had an impact on demand for private education. Moreover, it is also interesting to note that the tuition prices' standard deviations increased too.

Table 1. Monthly Grade 12 tuition fees

\begin{tabular}{cccccc}
\hline Year & Mean & $\begin{array}{c}\text { Standard } \\
\text { Deviation }\end{array}$ & Min & Max & N. of Obs. \\
\hline 2006 & 641.56 & 259.31 & 115.00 & 1428.00 & 76 \\
2007 & 613.36 & 261.69 & 111.50 & 1461.10 & 101 \\
2008 & 635.15 & 286.78 & 113.24 & 1482.28 & 104 \\
2009 & 683.04 & 286.85 & 160.39 & 1539.89 & 88 \\
\hline
\end{tabular}

Source: IBRE. Matched schools with INEP data only.

The samples for grade 2 tuition prices and for grade 6 tuition prices are not the same of the sample for grade 12 tuition prices. They are actually slightly smaller in size, because some

\footnotetext{
${ }^{8}$ It is worth noting that INEP, when organizing ENEM ranking, only considers schools with more than ten exam takers. For this reason, the dataset includes only schools with, at least, ten students who took the test on year $t$.
} 
schools offer only secondary (high school) education. Moreover, schools can legally charge different prices depending on grades. For this reason, descriptive statistics for those subsamples are also reported on Tables 2 and 3.

Table 2. Monthly Grade 2 tuition fees

\begin{tabular}{ccccccc}
\hline Year & Mean & $\begin{array}{c}\text { Standard } \\
\text { Deviation }\end{array}$ & Min & Max & N. of Obs. \\
\hline 2006 & 454.99 & 184.92 & 75.00 & 915.00 & 69 \\
2007 & 436.97 & 185.32 & 72.72 & 942.39 & 92 \\
2008 & 463.24 & 189.97 & 69.61 & 955.08 & 94 \\
2009 & 490.80 & 195.90 & 137.60 & 995.63 & 80 \\
\hline
\end{tabular}

Source: IBRE. Matched schools with INEP data only.

Table 3. Monthly Grade 6 tuition fees

\begin{tabular}{cccccc}
\hline Year & Mean & $\begin{array}{l}\text { Standard } \\
\text { Deviation }\end{array}$ & Min & Max & N. of Obs. \\
\hline 2006 & 513.58 & 224.91 & 115.00 & 1313.00 & 76 \\
2007 & 496.78 & 220.72 & 111.50 & 1342.82 & 98 \\
2008 & 518.14 & 237.31 & 113.24 & 1362.55 & 100 \\
2009 & 553.61 & 243.56 & 148.12 & 1415.44 & 85 \\
\hline
\end{tabular}

Source: IBRE. Matched schools with INEP data only.

Using ENEM data set, we constructed four main variables that were used in our analysis. ENEM exam is divided into two components. A test (multiple choice) and an writing exam. We used scores from the test part only. We then standardized it using the score distribution of all private schools in Brazil. That is our individual (school-level) ENEM score measure.

We also constructed standardized measures using local distribution of scores. That is our locally standardized ENEM score measure. ${ }^{9}$ We constructed a national rank variable: schools were ranked nationally in a way that the highest multiple choice score is ranked 1 and there is no correction for ties, i.e., the rank is 1 plus the number of values that are higher. Finally, we also constructed a local rank variable using the same reasoning as for the nation rank variable.

\footnotetext{
${ }^{9}$ By 'local' we mean for Belo Horizonte, Porto Alegre, Recife, Rio de Janeiro, Salvador, and São Paulo that we used city-level distribution. For Brasília, Guará, and Taguatinga, three cities that are part of the same metropolitan area, we used the metropolitan area-level distribution.
} 
Table 4 shows descriptive statistics of those variables for each grade. We index time according to tuition prices as we have done in the three previous tables. For example, in the next table, the line year 2006 shows descriptive statistics related to ENEM 2004.

Table 4. School quality proxies

\begin{tabular}{l|llll|lllll|llll}
\hline Panel A: National Standardized Multiple Choice Scores \\
\hline \multicolumn{1}{|c}{ Grade 2 } & \multicolumn{1}{l|}{ Grade 6 } & & & \multicolumn{3}{l}{ Grade 12 } \\
\hline Year & Mean & SD & Min & Max & Mean & SD & Min & Max & Mean & SD & Min & Max \\
\hline 2006 & 0.76 & 1.03 & -1.70 & 2.84 & 0.78 & 1.05 & -1.70 & 2.84 & 0.78 & 1.05 & -1.70 & 2.84 \\
2007 & 0.72 & 1.07 & -1.58 & 3.11 & 0.74 & 1.08 & -1.58 & 3.11 & 0.70 & 1.09 & -1.58 & 3.11 \\
2008 & 0.83 & 1.16 & -1.62 & 3.4 & 0.84 & 1.18 & -1.62 & 3.4 & 0.81 & 1.18 & -1.62 & 3.4 \\
2009 & 0.78 & 0.82 & -1.33 & 2.73 & 0.81 & 0.84 & -1.33 & 2.73 & 0.78 & 0.84 & -1.33 & 2.73 \\
\hline
\end{tabular}

Panel B: Local Standardized Multiple Choice Scores

\begin{tabular}{l|llll|lllll|llll}
\hline \multicolumn{5}{|c}{ Grade 2 } & \multicolumn{3}{l|}{ Grade 6 } & \multicolumn{4}{l}{ Grade 12 } \\
\hline Year & Mean & SD & Min & Max & Mean & SD & Min & Max & Mean & SD & Min & Max \\
\hline 2006 & 0.41 & 0.95 & -1.82 & 2.13 & 0.45 & 0.99 & -1.82 & 2.86 & 0.45 & 0.99 & -1.82 & 2.86 \\
2007 & 0.45 & 0.96 & -1.50 & 2.54 & 0.49 & 0.99 & -1.50 & 2.84 & 0.46 & 1.00 & -1.70 & 2.84 \\
2008 & 0.51 & 0.98 & -1.48 & 2.76 & 0.55 & 1.02 & -1.48 & 3.34 & 0.51 & 1.02 & -1.48 & 3.34 \\
2009 & 0.45 & 0.80 & -1.24 & 2.14 & 0.51 & 0.84 & -1.24 & 2.65 & 0.48 & 0.84 & -1.24 & 2.65 \\
\hline
\end{tabular}

Panel C: National Ranking

\begin{tabular}{l|llll|lllll|llll}
\hline \multicolumn{4}{|c}{ Grade 2 } & \multicolumn{3}{|l|}{ Grade 6 } & \multicolumn{3}{|l}{ Grade 12 } \\
\hline Year & Mean & SD & Min & Max & Mean & SD & Min & Max & Mean & SD & Min & Max \\
\hline 2006 & 1114 & 987 & 7 & 3532 & 1113 & 994 & 7 & 3532 & 1113 & 994 & 7 & 3532 \\
2007 & 1391 & 1230 & 2 & 4075 & 1374 & 1231 & 2 & 4075 & 1418 & 1245 & 2 & 4075 \\
2008 & 1256 & 1140 & 6 & 4012 & 1261 & 1150 & 6 & 4012 & 1296 & 1154 & 6 & 4012 \\
2009 & 1088 & 987 & 2 & 3562 & 1063 & 991 & 2 & 3562 & 1100 & 1000 & 2 & 3562 \\
\hline
\end{tabular}

Panel D: Local Ranking

\begin{tabular}{l|llll|lllll|llll}
\hline \multicolumn{5}{|c|}{ Grade 2 } & \multicolumn{3}{|c|}{ Grade 6 } & & \multicolumn{3}{|l}{ Grade 12 } & \\
\hline Year & Mean & SD & Min & Max & Mean & SD & Min & Max & Mean & SD & Min & Max \\
\hline 2006 & 64 & 84 & 1 & 352 & 62 & 82.1 & 1 & 352 & 62 & 82.1 & 1 & 352 \\
2007 & 63 & 78.7 & 1 & 381 & 61 & 78 & 1 & 381 & 61 & 77 & 1 & 381 \\
2008 & 57 & 71.1 & 1 & 321 & 55 & 70.3 & 1 & 321 & 55 & 69 & 1 & 321 \\
2009 & 49 & 64.3 & 1 & 345 & 47 & 63.5 & 1 & 345 & 47 & 62.5 & 1 & 345 \\
\hline
\end{tabular}

Source: INEP. Matched schools with IBRE data only.

\section{$4 \quad$ Identification Strategy}

In order to verify whether the disclosure of ENEM school average scores impacted private schools' tuitions, we will test the following model:

Model 1: One-period effect 


$$
\begin{aligned}
\text { tuition }_{i t}= & \gamma_{1} \\
\times & \text { school quality proxy } \\
& \times \text { year } 2009_{i t}+\beta_{2} \times\left(\text { year } 2007_{i t}+\beta_{2} \times{\text { year } 2008_{i t}}+\beta_{3}\right. \\
&
\end{aligned}
$$

where $i$ denotes school indexes; $t$ denotes time indexes; $\alpha_{i}$ is a school fixed effect that can be interpreted as, for example, school tradition, peer effects, students' demographic aspects, school inputs or any other variable that is fairly fixed during, at least, four years; $\varepsilon_{i t}$ is an exogenous shock; tuition $_{i t}$ can be the real tuitions of the grades 2, 6 and 12;

school quality proxy $_{i t}$ can be ENEM national standardized multiple choice scores, ENEM local standardized multiple choice scores, ENEM local ranks or ENEM national ranks; after 2006 is a dummy variable that assumes the value of 0 if $t=2006$ and the value of 1 otherwise.

The parameter $\gamma_{1}$ measures the impact of increasing school quality before the institutional change of making ENEM results public information; $\gamma_{2}$ measures the impact on tuition prices of the institutional change. The sum $\gamma_{1}+\gamma_{2}$ measures the impact of increasing school quality after the institutional change of making ENEM results public information.

The coefficient of interest is $\gamma_{2}$ and we employ fixed effects estimation method to guarantee that there is no bias coming from omitted variables that are time-invariant. A source of that kind of bias could have been, for example, school tradition. School tradition is fixed during short time horizons as the one analyzed in this work, but is likely to be correlated with ENEM scores and prices for the following reasons: (i) a more traditional school is likely to face a more inelastic demand curve and, therefore, charge higher tuition rates and (ii) a more traditional school is likely to attract innately better students and those students will achieve higher results, increasing school's average scores. For these reasons, the results would be biased without controlling for fixed effects. Moreover, during a short time period, such as four years, some variables - e.g. students' demographic aspects, peer effects, school inputs and school's price policy - can be considered as fairly fixed and, as a consequence, controlling for fixed effects will avoid any biases coming from not including those variables as regressors.

However, the important identification condition here is the exogeneity of the information disclosure rule. This institutional change is plausibly uncorrelated to unobservable 
determinants of tuition for all levels of school quality measures. This is due to the fact that Brazilian Education Ministry's decision was exogenous to school managers' decision making process. While parents will immediately adjust their demands for high and low quality schools, headmasters cannot change school inputs quickly enough to impact school scores and tuition prices. Moreover, parents' and headmasters' information set contains only year $t-2$ ENEM's results and any action took by school managers cannot have any impact on past and realized ENEM's school scores. Therefore, for identification of $\gamma_{2}$, it is not necessary to apply instrumental variable techniques, because the correlation between the error term (e.g. headmasters' decision about unobservable school inputs, such as effort) and the ENEM scores and/or rank variables have to be the same before and after the decision to release school averages.

Formally, our identification condition is given by:

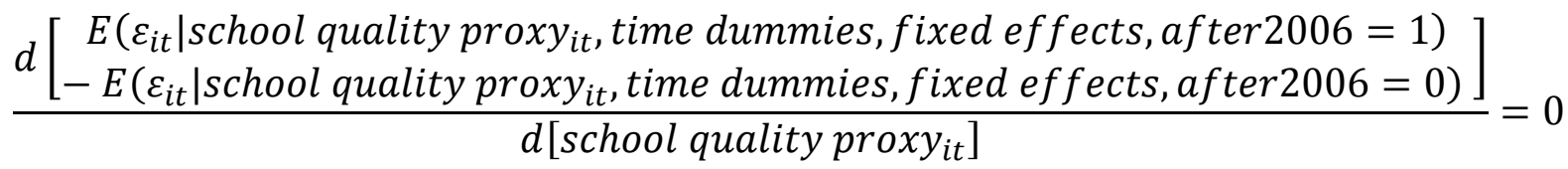

Moreover, on Model 1 we can identify parameter $\gamma_{2}$ as:

$\gamma_{2}$

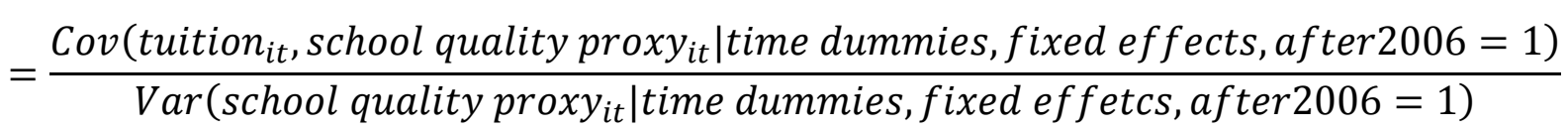

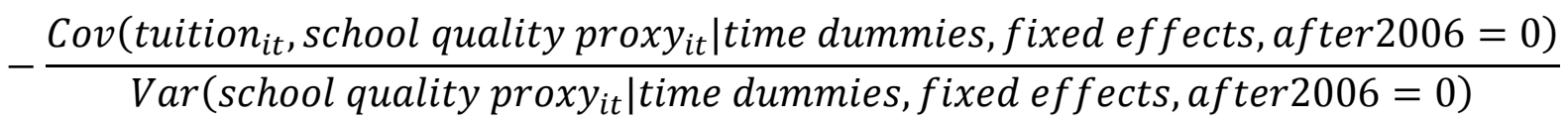

The interpretation of this coefficient is straightforward: if $\gamma_{2}$ is significant and positive, the disclosure of ENEM school results affected schools' tuitions by strengthening the correlation between prices and school quality measures, after the latter became visible to agents.

Moreover, it is also possible to test when exactly the impact of this institutional change affected prices. There are reasons to believe that the impact was not immediate, that is, the impact occurred in the first year of the publication of scores. For example, the impact might be increasing over time if parents need time to understand informational schemes and the policy maker might have had to conquer credibility. ${ }^{10}$ However, the impact could also be

\footnotetext{
${ }^{10}$ Mizala \& Urquiola (2013) raise that possibility for the Chilean case.
} 
decreasing over time. That would be the case in which parents believe that the ENEM signal about school quality is indeed noisier than initially expected. ${ }^{11}$ In order to test those different possibilities, we also try the following econometric model:

\section{Model 2: $\quad$ Multi-period effect}

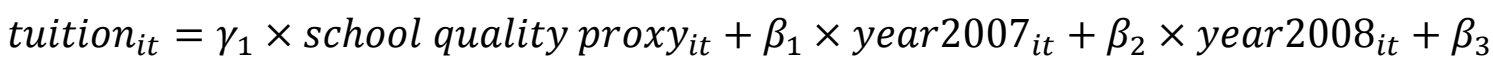

$$
\begin{aligned}
& \left.\times{\text { year } 2009_{i t}+\gamma_{2} \times(\text { year } 2007 \times \text { school quality proxy }}_{i t}\right)+\gamma_{3} \\
& \times\left(\text { year } 2008 \times \text { school quality proxy }{ }_{i t}\right)+\gamma_{4} \\
& \times\left(\text { year } 2009 \times \text { school quality proxy } y_{i t}\right)+\alpha_{i}+\varepsilon_{i t}
\end{aligned}
$$

where year2007, year2008 and year2009 are dummies for years 2007, 2008 and 2009, respectively.

It is important to note that identification of coefficients $\gamma_{2}, \gamma_{3}$ and $\gamma_{4}$ of this model follows by the same reasons that the coefficient $\gamma_{2}$ of the previous model was identified too. Formally, the identification condition for $\gamma_{2}, \gamma_{3}$ and $\gamma_{4}$, as well as their formulas, are very similar to the ones stated above. For this reason and conciseness, they are not explicitly written here. Their interpretation is also straightforward: if they are increasing, that is, if $\gamma_{2}<\gamma_{3}<\gamma_{4}$, then the price reaction originated by the disclosure of ENEM results is getting more intense due to the fact that agents got a better understanding about how ENEM works. If it is decreasing, that is, if $\gamma_{2}>\gamma_{3}>\gamma_{4}$, then ENEM was probably a noisier signal of school quality than agents initially expected.

Time dummies were added in both models in order to control for factors that change during the years, but that do not change among schools, such as national-wide consumer's behavior, income increases and changes in income distribution. Moreover, when running the fixedeffect regressions, a constant will be added to the model and a robust variance matrix will be employed in order to allow for heteroscedasticity. Finally, all models were subjected to two selection bias tests and both tests did not reject the null hypothesis that there is no selection bias.

The first test of selection, the lagged selection indicator test, ${ }^{12}$ consists of adding to the regression a dummy (lagged selection indicator), named $S$, that assumes the value of 1 if

\footnotetext{
${ }^{11}$ That is a phenomenon that happened in Florida and was documented by Figlio \& Lucas (2004).
} 
school $i$ was present in the sample in year $t-1$ and the value of 0 otherwise. Under the null hypothesis, $\varepsilon_{i t}$ is uncorrelated with selection indicators for any $t$. Hence, selection in the previous time period should not be significant in the equation at time $t$. If, when running this test, ${ }^{13}$ some variables are omitted due to multicollinearity, this phenomenon is even stronger evidence that there is no selection bias, because the missing information problem due to a possible selection bias is really too small. The results for this test are reported in the Appendix.

The second test, the leavers test, is based on Becketti, Gould, Lillard \& Welch (1988) and consists of adding to the model interactions between all the independent variables and a dummy, called $L$, that assumes the value of 0 if school $i$ is present in the sample for all the four years and 1 otherwise. Then, this test is implemented through a regression with data only for the first time period, compensating for the information loss of the first test. Under the null hypothesis, all the interactions must be non-significant. If, when running this test, some variables are omitted due to multicollinearity, this phenomenon is even stronger evidence that there is no selection bias, because the missing information problem due to a possible selection bias is really too small. Results for this test are similar to the previous one and we omitted them in this version (they are available upon request).

\section{$5 \quad$ Results}

This section contains four tables and each one is divided into two panels. While the second panel of each table presents the fixed-effects regressions described in the previous section, the first panel presents the ordinary least squares regressions associated to each one of them. Each table shows our results using a different school quality proxy that is indicated by its initials. While the interaction terms after $2006 \times$ school quality proxy of the one-period models are named as 2006_'initials', the interaction terms year $\times$ school quality proxy of the multi-period models are named as year_'initials'.

\footnotetext{
${ }^{12}$ This procedure is well explained at section 17.7.2 of Wooldridge (2001).

${ }^{13}$ When this test is implemented, information about the first time period is lost.
} 
Table 5. National Standardized Multiple Choice Scores (NSMCS) as school quality proxy

\begin{tabular}{|c|c|c|c|c|c|c|}
\hline \multicolumn{7}{|c|}{ Panel A: Ordinary Least Squares Regressions } \\
\hline Variable & $\begin{array}{l}(1) \\
\text { Grade 2: } \\
\text { One- } \\
\text { period }\end{array}$ & $\begin{array}{l}(2) \\
\text { Grade 2: } \\
\text { Multi- } \\
\text { period }\end{array}$ & $\begin{array}{l}(3) \\
\text { Grade 6: } \\
\text { One- } \\
\text { period }\end{array}$ & $\begin{array}{l}\text { (4) } \\
\text { Grade 6: } \\
\text { Multi- } \\
\text { period }\end{array}$ & $\begin{array}{l}(5) \\
\text { Grade } \\
\text { 12: One- } \\
\text { period }\end{array}$ & $\begin{array}{l}(6) \\
\text { Grade } \\
12: \\
\text { Multi- } \\
\text { period }\end{array}$ \\
\hline NSMCS & $\begin{array}{l}112.3 * * * \\
(15.19)\end{array}$ & $\begin{array}{l}112.3 * * * \\
(15.23)\end{array}$ & $\begin{array}{l}134.7 * * * \\
(21.35)\end{array}$ & $\begin{array}{l}134.7 * * * \\
(21.42)\end{array}$ & $\begin{array}{l}176.7 * * * \\
(21.53)\end{array}$ & $\begin{array}{l}176.7 * * * \\
(21.59)\end{array}$ \\
\hline After 2006_NSMCS & $\begin{array}{l}5.223 \\
(17.37)\end{array}$ & - & $\begin{array}{l}9.714 \\
(24.26)\end{array}$ & - & $\begin{array}{l}14.49 \\
(24.62)\end{array}$ & - \\
\hline 2007_NSMCS & - & $\begin{array}{l}2.019 \\
(20.31)\end{array}$ & - & $\begin{array}{l}-1.164 \\
(28.22)\end{array}$ & - & $\begin{array}{l}.00889 \\
(28.35)\end{array}$ \\
\hline 2008_NSMCS & - & $\begin{array}{l}-2.721 \\
(19.59)\end{array}$ & - & $\begin{array}{l}2.918 \\
(27.43)\end{array}$ & - & $\begin{array}{l}5.767 \\
(28.11)\end{array}$ \\
\hline 2009_NSMCS & - & $\begin{array}{l}30.03 \\
(26.22)\end{array}$ & - & $\begin{array}{l}46.49 \\
(35.23)\end{array}$ & - & $\begin{array}{l}62.49 * \\
(36.31)\end{array}$ \\
\hline Observations & 335 & 335 & 359 & 359 & 369 & 369 \\
\hline R-squared & .412 & .416 & .422 & .427 & .526 & .533 \\
\hline \multicolumn{7}{|c|}{ Panel B: Fixed-Effects Regressions } \\
\hline Variable & $\begin{array}{l}\text { (7) } \\
\text { Grade 2: } \\
\text { One- } \\
\text { period }\end{array}$ & $\begin{array}{l}\text { (8) } \\
\text { Grade 2: } \\
\text { Multi- } \\
\text { period }\end{array}$ & $\begin{array}{l}\text { (9) } \\
\text { Grade 6: } \\
\text { One- } \\
\text { period }\end{array}$ & $\begin{array}{l}\text { (10) } \\
\text { Grade 6: } \\
\text { Multi- } \\
\text { period }\end{array}$ & $\begin{array}{l}\text { (11) } \\
\text { Grade } \\
\text { 12: One- } \\
\text { period }\end{array}$ & $\begin{array}{l}(12) \\
\text { Grade } \\
12: \\
\text { Multi- } \\
\text { period }\end{array}$ \\
\hline NSMCS & $\begin{array}{l}-5.115 \\
(4.997)\end{array}$ & $\begin{array}{l}-3.408 \\
(5.043)\end{array}$ & $\begin{array}{l}-10.34^{* * *} \\
(5.19)\end{array}$ & $\begin{array}{l}-7.983 \\
(4.861)\end{array}$ & $\begin{array}{l}-7.274 \\
(7.016)\end{array}$ & $\begin{array}{l}-4.012 \\
(6.63)\end{array}$ \\
\hline After 2006_NSMCS & $\begin{array}{l}4.195^{*} \\
(2.426)\end{array}$ & - & $\begin{array}{l}10.09 * * * \\
(2.502)\end{array}$ & - & $\begin{array}{l}9.756 * * * \\
(3.398)\end{array}$ & - \\
\hline 2007_NSMCS & - & $\begin{array}{l}.883 \\
(1.808)\end{array}$ & - & $\begin{array}{l}3.547 * \\
(1.973)\end{array}$ & - & $\begin{array}{l}.897 \\
(2.551)\end{array}$ \\
\hline 2008_NSMCS & - & $\begin{array}{l}3.095 \\
(3.166)\end{array}$ & - & $\begin{array}{l}9.518 * * * \\
(3.174)\end{array}$ & - & $\begin{array}{l}8.658 * * \\
(4.044)\end{array}$ \\
\hline 2009_NSMCS & - & $\begin{array}{l}14.20 * * \\
(5.489)\end{array}$ & - & $\begin{array}{l}24.97 * * * \\
(5.462)\end{array}$ & - & $\begin{array}{l}30.55 * * * \\
(7.366)\end{array}$ \\
\hline $\begin{array}{l}\text { Observations } \\
\text { R-squared }\end{array}$ & $\begin{array}{l}335 \\
.296\end{array}$ & $\begin{array}{l}335 \\
.334\end{array}$ & $\begin{array}{l}359 \\
.308\end{array}$ & $\begin{array}{l}359 \\
.388\end{array}$ & $\begin{array}{l}369 \\
.280\end{array}$ & $\begin{array}{l}369 \\
.368\end{array}$ \\
\hline
\end{tabular}

Notes: (i) Robust standard errors in parentheses. (ii) Symbols ***, ** and * indicate respectively p-values, p, such that $\mathrm{p}<.01, \mathrm{p}<.05$, and $\mathrm{p}<.1$. (iii) Time dummies and a constant were added in all models, but their coefficients are not reported here. 
Table 6. National ranking (NR) as school quality proxy

\begin{tabular}{|c|c|c|c|c|c|c|}
\hline \multicolumn{7}{|c|}{ Panel A: Ordinary Least Squares Regressions } \\
\hline Variable & $\begin{array}{l}(13) \\
\text { Grade } \\
\text { 2: One- } \\
\text { period }\end{array}$ & $\begin{array}{l}\text { (14) } \\
\text { Grade } \\
\text { 2: } \\
\text { Multi- } \\
\text { period } \\
\end{array}$ & $\begin{array}{l}(15) \\
\text { Grade 6: } \\
\text { One- } \\
\text { period }\end{array}$ & $\begin{array}{l}\text { (16) } \\
\text { Grade 6: } \\
\text { Multi- } \\
\text { period }\end{array}$ & $\begin{array}{l}(17) \\
\text { Grade 12: } \\
\text { One- } \\
\text { period }\end{array}$ & $\begin{array}{l}(18) \\
\text { Grade } \\
12: \\
\text { Multi- } \\
\text { period }\end{array}$ \\
\hline NR & $\begin{array}{l}-.122 * * * \\
(.0159)\end{array}$ & $\begin{array}{l}-.122 * * * \\
(.016)\end{array}$ & $\begin{array}{l}-.144 * * * \\
(.0195)\end{array}$ & $\begin{array}{l}-.144 * * * \\
(0.0196)\end{array}$ & $\begin{array}{l}-.186 * * * \\
(.0209)\end{array}$ & $\begin{array}{l}-.186^{* * * *} \\
(0.021)\end{array}$ \\
\hline After 2006_NR & $\begin{array}{l}.0114 \\
(.0175)\end{array}$ & - & $\begin{array}{l}(.0111) \\
(.0215)\end{array}$ & - & $\begin{array}{l}.0126 \\
(.0231)\end{array}$ & - \\
\hline 2007_NR & - & $\begin{array}{l}.0208 \\
(.0199)\end{array}$ & - & $\begin{array}{l}.0278 \\
(.0242)\end{array}$ & - & $\begin{array}{l}.035 \\
(.026)\end{array}$ \\
\hline 2008_NR & - & $\begin{array}{l}.00572 \\
(.0188)\end{array}$ & - & $\begin{array}{l}.0004 \\
(.0237)\end{array}$ & - & $\begin{array}{l}-.00172 \\
(.0256)\end{array}$ \\
\hline 2009_NR & - & $\begin{array}{l}.0036 \\
(.024)\end{array}$ & - & $\begin{array}{l}-.00171 \\
(.0288)\end{array}$ & - & $\begin{array}{l}-.00483 \\
(.0315)\end{array}$ \\
\hline Observations & 335 & 335 & 359 & 359 & 369 & 369 \\
\hline R-squared & .433 & .435 & .420 & .423 & .511 & .516 \\
\hline \multicolumn{7}{|c|}{ Panel B: Fixed-Effects Regressions } \\
\hline Variable & $\begin{array}{l}(19) \\
\text { Grade } \\
\text { 2: One- } \\
\text { period }\end{array}$ & $\begin{array}{l}\text { (20) } \\
\text { Grade } \\
\text { 2: } \\
\text { Multi- } \\
\text { period } \\
\end{array}$ & $\begin{array}{l}(21) \\
\text { Grade 6: } \\
\text { One- } \\
\text { period }\end{array}$ & $\begin{array}{l}(22) \\
\text { Grade 6: } \\
\text { Multi- } \\
\text { period }\end{array}$ & $\begin{array}{l}(23) \\
\text { Grade 12: } \\
\text { One- } \\
\text { period }\end{array}$ & $\begin{array}{l}(24) \\
\text { Grade } \\
\text { 12: } \\
\text { Multi- } \\
\text { period } \\
\end{array}$ \\
\hline NR & $\begin{array}{l}.0022 \\
(.00584)\end{array}$ & $\begin{array}{l}.00207 \\
(.00559)\end{array}$ & $\begin{array}{l}.00805 \\
(.00624)\end{array}$ & $\begin{array}{l}.00749 \\
(.00573)\end{array}$ & $\begin{array}{l}.00245 \\
(.00767)\end{array}$ & $\begin{array}{l}.00194 \\
(.00719)\end{array}$ \\
\hline After 2006_NR & $\begin{array}{l}-.00367 \\
(.00276)\end{array}$ & - & $\begin{array}{l}-.00957 * * * \\
(.00263)\end{array}$ & - & $\begin{array}{l}-.00943 * * * \\
(.0034)\end{array}$ & - \\
\hline 2007_NR & - & $\begin{array}{l}.00164 \\
(.00203)\end{array}$ & - & $\begin{array}{l}-.00490 * * \\
(.002)\end{array}$ & - & $\begin{array}{l}-.00221 \\
(.00255)\end{array}$ \\
\hline 2008_NR & - & $\begin{array}{l}.00218 \\
(.00346)\end{array}$ & - & $\begin{array}{l}-.00848 * * * \\
(.00318)\end{array}$ & - & $\begin{array}{l}-.00884 * * \\
(.00391)\end{array}$ \\
\hline 2009_NR & - & $\begin{array}{l}-.0104 * * \\
(.00471)\end{array}$ & - & $\begin{array}{l}-.0203 * * * \\
(.00472)\end{array}$ & - & $\begin{array}{l}-.0240 * * * \\
.00621)\end{array}$ \\
\hline $\begin{array}{l}\text { Observations } \\
\text { R-squared }\end{array}$ & $\begin{array}{l}335 \\
.294 \\
\end{array}$ & $\begin{array}{l}335 \\
.319 \\
\end{array}$ & $\begin{array}{l}359 \\
.302 \\
\end{array}$ & $\begin{array}{l}359 \\
.358 \\
\end{array}$ & $\begin{array}{l}369 \\
.281 \\
\end{array}$ & $\begin{array}{l}369 \\
.345 \\
\end{array}$ \\
\hline
\end{tabular}

Notes: (i) Robust standard errors in parentheses. (ii) Symbols ***, ** and * indicate respectively p-values, p, such that $\mathrm{p}<.01, \mathrm{p}<.05$, and $\mathrm{p}<.1$. (iii) Time dummies and a constant were added in all models, but their coefficients are not reported here. 
Table 7. Local ranking (LR) as school quality proxy

\begin{tabular}{|c|c|c|c|c|c|c|}
\hline \multicolumn{7}{|c|}{ Panel A: Ordinary Least Squares Regressions } \\
\hline \multirow[b]{2}{*}{ Variable } & (25) & (26) & (27) & (28) & (29) & (30) \\
\hline & $\begin{array}{l}\text { Grade 2: } \\
\text { One- } \\
\text { period }\end{array}$ & $\begin{array}{l}\text { Grade 2: } \\
\text { Multi- } \\
\text { period }\end{array}$ & $\begin{array}{l}\text { Grade 6: } \\
\text { One- } \\
\text { period }\end{array}$ & $\begin{array}{l}\text { Grade 6: } \\
\text { Multi- } \\
\text { period }\end{array}$ & $\begin{array}{l}\text { Grade 12: } \\
\text { One- } \\
\text { period }\end{array}$ & $\begin{array}{l}\text { Grade } \\
\text { 12: } \\
\text { Multi- } \\
\text { period }\end{array}$ \\
\hline \multirow[t]{2}{*}{ LR } & $-.383 * * *$ & $-.383 * * *$ & $-.510 * *$ & $-.510 * *$ & $-.827 * * *$ & $-.827 * * *$ \\
\hline & $(.146)$ & $(.147)$ & $(.199)$ & $(.199)$ & $(.235)$ & $(.236)$ \\
\hline \multirow[t]{2}{*}{ After 2006_LR } & -.234 & & -.274 & & -.281 & \\
\hline & $(.192)$ & - & $(.251)$ & - & $(.302)$ & - \\
\hline \multirow[t]{2}{*}{ 2007_LR } & - & -.13 & - & -.133 & & -.119 \\
\hline & & $(.261)$ & - & $(.324)$ & - & $(.391)$ \\
\hline \multirow[t]{2}{*}{ 2008_LR } & - & $-.469 *$ & - & $-.531 *$ & - & -.575 \\
\hline & - & $(.24)$ & - & $(.306)$ & - & $(.383)$ \\
\hline \multirow[t]{2}{*}{ 2009_LR } & & -.076 & & -.149 & & -.137 \\
\hline & - & $(.244)$ & - & $(.342)$ & - & $(.408)$ \\
\hline Observations & 335 & 335 & 359 & 359 & 369 & 369 \\
\hline R-squared & .060 & .063 & .060 & .063 & .084 & .086 \\
\hline \multicolumn{7}{|c|}{ Panel B: Fixed-Effects Regressions } \\
\hline \multirow[b]{2}{*}{ Variable } & (31) & (32) & (33) & (34) & (35) & (36) \\
\hline & $\begin{array}{l}\text { Grade 2: } \\
\text { One- } \\
\text { period }\end{array}$ & $\begin{array}{l}\text { Grade 2: } \\
\text { Multi- } \\
\text { period }\end{array}$ & $\begin{array}{l}\text { Grade 6: } \\
\text { One- } \\
\text { period }\end{array}$ & $\begin{array}{l}\text { Grade 6: } \\
\text { Multi- } \\
\text { period }\end{array}$ & $\begin{array}{l}\text { Grade 12: } \\
\text { One- } \\
\text { period }\end{array}$ & $\begin{array}{l}\text { Grade } \\
\text { 12: } \\
\text { Multi- } \\
\text { period }\end{array}$ \\
\hline \multirow[t]{2}{*}{ LR } & .0762 & .0467 & .141 & .0733 & .126 & .0546 \\
\hline & $(.076)$ & $(.0851)$ & $(.0912)$ & $(.1)$ & $(.0984)$ & $(.112)$ \\
\hline \multirow[t]{2}{*}{ After 2006_LR } & $-.0410 *$ & - & $-.0918 * * *$ & $\ldots$ & $-.0976 * * *$ & $\ldots$ \\
\hline & $(.0218)$ & & $(0.03)$ & & $(.035)$ & - \\
\hline \multirow[t]{2}{*}{ 2007_LR } & - & -.012 & - & -.0238 & - & -.0149 \\
\hline & & $(.0204)$ & & $(.0224)$ & & $(.026)$ \\
\hline \multirow[t]{2}{*}{ 2008_LR } & & -.0281 & & $-.0817 * *$ & & $-.117 * *$ \\
\hline & - & $(.0312)$ & - & $(.041)$ & - & $(.0476)$ \\
\hline \multirow[t]{2}{*}{ 2009_LR } & & $-.104 * *$ & & $-.215^{* * *}$ & & $-.207 * *$ \\
\hline & & $(.0474)$ & & $(.0807)$ & & $(.0829)$ \\
\hline Observations & 335 & 335 & 359 & 359 & 369 & 369 \\
\hline R-squared & .294 & .305 & .294 & .331 & .273 & .295 \\
\hline
\end{tabular}

Notes: (i) Robust standard errors in parentheses. (ii) Symbols ***, ** and * indicate respectively p-values, p, such that $\mathrm{p}<.01, \mathrm{p}<.05$, and $\mathrm{p}<.1$. (iii) Time dummies and a constant were added in all models, but their coefficients are not reported here.

We first analyze the results regarding Grade 12 tuition prices in the one-period model. We note that, when OLS columns and Fixed-Effects columns are compared in any table, OLS 
estimations are biased because they do not control for unobserved variables, e.g. school reputation. When unobserved effects are controlled for, the coefficients associated to the school quality proxy lose significance, suggesting that ENEM average scores and school reputation are closely correlated as initially expected, and the interaction terms after $2006 \times$ school quality proxy becomes significant with the expected sign. More specifically, after the 2006 institutional change that started providing ENEM school averages to the public, the partial effect of all our school quality proxies on tuition prices increased. Analyzing regression (11) and considering that NSMCS's coefficient is non-significant, we find that, after 2006, if a school was able to increase its average national standardized multiple choice score by one standard deviation, tuition would be raised by $\mathrm{R} \$ 9.76$. That represents an increase of $1.5 \%$ in 2006 grade 12 tuitions.

There exists another interpretation for $\gamma_{2}$ that is also important to mention. Since the coefficients associated to the school quality proxy are statistically equal to zero when we control for fixed effects, we know, from section 4, that $\gamma_{2}$

$=\frac{\left.\operatorname{Cov} \text { (tuition }_{\text {it }}, \text { school quality prox }_{i t} \mid \text { time dummies, fixed effects, after } 2006=1\right)}{\operatorname{Var}\left(\text { school quality proxy }_{i t} \mid \text { time dummies, fixed effetcs, after } 2006=1\right)}$ Multiplying it by

$$
\frac{s d\left(\text { school quality proxy }_{\text {it }} \mid \text { time dummies, fixed effects, after } 2006=1\right)}{s d\left(\text { tuition }_{i t} \mid \text { time dummies, fixed effects, after } 2006=1\right)}
$$
we can interpret this number as an increase in the correlation between monthly tuition prices and our school quality proxy from zero to a positive number. This increase was provoked by the new information about school quality created by the disclosure of ENEM average school scores. Looking regression (11) and knowing that the standard deviation of NSMCS and Grade 12 tuitions after 2006 are, respectively, 1.056 and 278.408, we find that the disclosure of ENEM average scores increased the correlation between NSMCS and tuition prices by $0.037 .^{14}$

In the Appendix, we show the results when local standardized multiple choice scores are used. The impact on tuition prices are slightly larger (11.02). We find that, after 2006, if a school was able to increase its average local standardized multiple choice score by one standard

\footnotetext{
${ }^{14}$ This number is just an approximation since our standard deviation measures do not control for fixed effects nor time dummies.
} 
deviation, tuition could be increased by $1.7 \%$ when compared with 2006 grade 12 tuitions. Moreover, after calculations similar to the ones developed in the previous paragraph, the disclosure of average school scores provoked an increase of 0.038 in the correlation between LSMCS and tuition prices. This suggests that local private education markets are more responsive to new information on school quality than the national one.

The rank regressions provide similar results when compared to the standardized score regressions, giving even stronger evidence that there is a price reaction to the disclosure of ENEM school average scores. Note that the negative sign is actually a consequence of the fact the main regressor in those tables (national and local rankings) decreases with school quality. The local effect using rankings is almost 10 times higher than using the national ranking. This was expected since parents set choice is usually constrained to schools in the same municipality. Therefore, a local ranking adds more information to the school choice decision than a national one.

Now, we analyze the results regarding Grade 12 tuition prices in the multi-period model. Regression (12) shows that ENEM school average scores publication impact on tuition prices gets stronger with time. This result is supported by t-tests, because $\gamma_{2} \neq \gamma_{3}$ at the 5-percent significance level and $\gamma_{3} \neq \gamma_{4}$ at the 1-percent significance level. Intuitively, this result means that parents started paying close attention to ENEM scores after they actually understood this standardized test, a learning process that took time, as suggested by Mizala \& Urquiola (2013). This phenomenon can also be explained by building up exam reputation. ENEM organizers needed to build up a credible reputation about ENEM's fairness and difficulty. Moreover, the conclusions achieved for the one-period model are still valid for this part and their economic significance is even larger due to $\gamma_{4}$ magnitude. Analyzing regression (24), we find that, in 2009, if a school was able to increase its average national standardized multiple choice score by one standard deviation, tuition could be increased by $4.5 \%$ when compared with 2009 grade 12 tuitions.

Again, the local standardized scores presents very similar results when compared to national ones, giving stronger evidence that the price reaction provoked by the disclosure of ENEM school average scores got stronger with time. Moreover, the ranking regressions show stronger evidence that the price reaction provoked by the disclosure of ENEM school average 
scores increases with time. Interestingly, local rankings produce effects that are about ten times larger than national rankings.

Now, we analyze the results regarding Grade 2 tuition prices in the one-period model because their comparison with the results related to Grade 12 tuition prices is more interesting. According to regression (7), we note that, the fixed-effect estimate of $\gamma_{2}$ (coefficient of 2006_NSMCS) are smaller than the OLS estimate, revealing that unobservable time invariant determinants of tuitions, such as school reputation, affect positively tuition prices. Also, it is important to note that ENEM is taken on grade 12, so one would expect that the transmission to the prices of earlier grades would have a weaker effect. In fact, the effect on regression (7) is about half of that encountered on regression (11). More specifically, after the 2006 institutional change that started providing ENEM school averages to the public, the partial effect of average national standardized multiple choice scores on tuition prices increased by 4.195. That represents an increase of $0.9 \%$ in 2006 grade 2 tuitions. Again, we can interpret $\gamma_{2}$, after multiplying it by the correct ratio between the standard deviation of NSMCS and of Grade 2 tuition prices after 2006, as an increase in the correlation between NSMCS and Grade 2 tuition prices. More specifically, we find that the disclosure of average school scores increased this correlation by 0.023 , providing further evidence that the new information about school quality has an impact on elementary education, although it is weaker than its impact on high school tuition prices.

Again, the local score and national and local ranking regression presents very similar results. However, when we use ENEM results that are relative to the local markets, the effects of publication on prices are even more prominent than national ones, giving stronger evidence that there is a price reaction to the disclosure of ENEM school average scores even on earlier grades.

The fact that effects on tuition prices at grade 2 are about half of those on grade 12 is very intuitive. Parents, when deciding to enroll their kids at elementary school, may have other concerns than getting their kids into college, such as a humanitarian, cultural or political education, and it would be very surprising to find effects of the same magnitude of grade 12 on grade 2 tuition prices. 
We also analyze the results regarding Grade 2 tuition prices in the multi-period model. Although both score and ranking regressions suggest the price reaction provoked by the disclosure of ENEM school average scores in the market for earlier grades of elementary education got stronger with time, this process was longer and weaker than the process for high schools. This statement is supported by the fact that $\gamma_{2}$ is statistically equal to $\gamma_{3}$ in the those regressions, although $\gamma_{3}$ is statistically different than $\gamma_{4}$. Also, local rankings are 10 times more important than national rankings for price determination. Those findings support the already mentioned view that parents may have other concerns than getting their kids into college when enrolling six years old children at school. For this reason, they took a longer time to believe that ENEM was actually a good sign about school quality relative to those other concerns.

To conclude this section, we analyze the results regarding Grade 6 tuition prices. In the oneperiod model, the results show that the disclosure of ENEM school average scores caused a price reaction in the market of middle schools as strong as the reaction in the market of high schools. This statement is supported by the fact that $\gamma_{2}$ in the models with grade 6 tuition prices is similar in size and significance to $\gamma_{2}$ in the models with grade 12 tuition prices. Regarding the multi-period model, the results suggest the effect might have taken more time to kick in compared to the senior year of high school.

\section{Conclusion}

School accountability systems are powerful tools to promote school quality enhancements. For this reason, many local and national governments around the world have implemented those systems. However, most of these initiatives were concerned with public education instead of private education. For this same reason, the largest part of research about school accountability considered only public education and the impact of this system on students' achievement. Any measure on willingness to pay for quality had to use information on housing prices or local taxes.

By looking at the Brazilian private education system, whose enrolment share is about $20 \%$, we are able to measure directly the link between school quality and prices charged. Our results show that the publication of ENEM to parents affected the prices charged by schools: higher quality (higher ENEM scores) schools charged even higher prices than lower quality ones. Such positive correlation between ENEM scores and prices existed before the decision 
to make average scores public, as ENEM may correlate with unobserved to the econometrician school attributes that affect school prices. However, that correlation became even stronger, revealing that ENEM scores are useful measures of school quality.

More precisely, after analyzing a panel data set about tuition prices and ENEM average scores using a fixed effect estimation method, three main results were found:

i. The disclosure of ENEM school average scores had a significant impact on tuition prices, suggesting that parents do consider ENEM results a proxy for school quality when they take the decision about where to enroll their children. As a consequence, there is some evidence that ENEM score publication established a free market school accountability system, because schools are rewarded and punished based on their averages scores on this standardized national test. It is also interesting to note that this accountability system holds not only for final grades of basic education but for elementary and middle schools as well.

ii. ENEM school average scores publication did not have an immediate impact on tuition prices. There was a time delay between this institutional change and its impact on the private education market. This phenomenon is likely to be due to a parents' learning process about ENEM fairness and hardness or to an initial lack of credibility related to government's ability to organize such an important test.

iii. Private education markets in Brazil are local instead of national, implying that agents are unlikely to move from one state to another in order to enroll their kids at a better school, an unsurprising result given the dimensions of the country.

Given that private schools cannot immediately change and/or increase prices as there are institutional restrictions to when and by how much prices can increase, our results can be seen as a lower bound between information disclosure on quality and tuition practices. Without those restrictions it is reasonable to believe that one would be able to find even more prominent effects of publication of scores on prices.

It is worth noting that the conclusions about price reactions are robust to model specification. We tried four distinct measures of school quality (nationally and locally standardized results and rankings), prices for three different grades (grades 2, 6 and 12). Furthermore, we also ran but did not report here models using nominal prices instead of real prices and models adding school-level covariates. Results for those unreported models are similar to the ones presented and that is why we omitted them (they are available upon request). Very importantly, in one 
of the unreported models we added the number of students taking ENEM per school as a covariate. Results do not change, revealing that even controlling for 'quantity', quality impacts on prices.

Finally, according to the above mentioned results, it is possible to make the following public policy recommendations:

i. It is actually possible to reward school quality through a free market mechanism if the agents have enough information about it. This finding suggests that private school regulation (e.g. a very strict national curriculum or minimum number of hours spent in a classroom) are not the only solution to increase school quality, because, if the agents are free to choose among schools and have information about them, parents will demand high quality, enroll their kids at better schools and reward those schools through higher tuition prices and, consequently, higher profits. Therefore, an education system based on competition among schools is likely to provide the correct market incentives to schools and force them to increase quality, because parents' school choice and willingness-to-pay depend on information about school quality.

ii. Education public policy takes time to present its results. For this reason, a policy cannot be implemented and, later, ignored if its results are not rapidly clear. After adopting a specific public policy for education, the government must wait for results to 'kick-in' before taking the decision on to continue this policy or not. This finding also means that the government must make a deep analysis before implementing a policy, because it has sunk and time costs related to institutional credibility.

iii. If education markets are local instead of national, education policy and regulation should be local too. Therefore, there seems to be gains in decentralizing public education and/or educational policies.

\section{$7 \quad$ References}

ANDRABI, T., J. DAS \& A. KHWAJA (2014) "Report Cards: The Impact of Providing School and Child Test Scores on Educational Markets," unpublished manuscript, Harvard University. < http://www.hks.harvard.edu/fs/akhwaja/papers/RC_June2014.pdf >

BECKETTI, S., W. GOULD, L. LILLARD \& F. WELCH. (1988) "The Panel Study of Income Dynamics after Fourteen Years: An Evaluation”. Journal of Labor Economics, 6 (4), 472-492.

BLACK, S. (1999) "Do better schools matter? Parental valuation of Elementary Education." Quarterly Journal of Economics, 114 (2), 577-599.

BRASIL. Lei no 9.870, de 23 de novembro de 1999. Available at: <http://www2.camara.gov.br/legin/fed/lei/1999/lei-9870-23-novembro-1999-369698-normapl.html>. Accessed on: September, 16 ${ }^{\text {th }}, 2012$. 
BRASINGTON, D. (1999) "Which measures of school quality does the housing market value?." Journal of Real Estate Research, 18 (3), 395-413.

CAMARGO, B., R. CAMELO, S. FIRPO \& V. PONCZEK. (2014) "Information, Market Incentives, and Student Performance.” IZA Discussion Paper No. 7941. Available at: <http://ftp.iza.org/dp7941.pdf>. Accessed on: July, 21 ${ }^{\text {st }}, 2014$

CLAPP, J., A. NANDA, \& S. ROSS. (2008) "Which school attributes matter? The influence of school district performance and demographic composition on property values." Journal of Urban Economics, 63 (2), 451-466.

DAVIDOFF, I., \& A. LEIGH. (2008) "How Much do Public Schools Really Cost? Estimating the Relationship between House Prices and School Quality." Economic Record, 84 (265), 193-206.

DOWNES, T., \& J. ZABEL. (2002) "The impact of school characteristics on house prices: Chicago 1987-1991." Journal of Urban Economics, 52 (1), 1-25.

FACK, G. \& J. GRENET. (2010) "When do better schools raise housing prices? Evidence from Paris public and private schools". Journal of Public Economics, 94, 59-77.

FIGLIO, D. \& M. LUCAS. (2004) "What's in Grade? School Report Cards and the Housing Market". The American Economic Review, 94 (3), 591-604.

FIGLIO, D. \& S. LOEB. (2011) "School Accountability". In: HANUSHEK, E., S. MACHIN \& L. WOESSMANN (Eds.) Handbook of Economics of Education, Volume 3. Amsterdam: NorthHolland, p. 383-421.

GIBBONS, S., \& S. MACHIN. (2003) "Valuing English primary schools.” Journal of Urban Economics, 53 (2), 197-219.

GIBBONS, S., \& S. MACHIN. (2008) "Valuing school quality, better transport, and lower crime: evidence from house prices." Oxford Review of Economic Policy, 24 (1), 99-119.

HASTINGS, J., R. van WEELDEN \& J. WEINSTEIN. (2007) "Preferences, Information, and Parental Choice Behavior in Public School Choice". NBER Working Papers 12995. Available at: < http://www.nber.org/papers/w12995.pdf > . Accessed on: July, $16^{\text {th }}, 2014$.

HAURIN, D., \& D. BRASINGTON. (1996) "School quality and real house prices: Inter-and intrametropolitan effects." Journal of Housing Economics, 5 (4), 351-368.

INEP-MEC. (2006) "Notas Médias do Enem 2006 por Município e por Escola dos Alunos Concluintes do Ensino Médio em 2006". Nota Técnica. Available at: $\left\langle\right.$ http://www.afrobras.org.br/pesquisas/enem-nota-tecnica.pdf $>$. Accessed on: September, $16^{\text {th }}$, 2012.

KANE, T., S. RIEGG, \& D. STAIGER. (2006) "School quality, neighborhoods, and housing prices." American Law and Economics Review, 8 (2), 183-212.

KONING, P. \& K. van der WIEL. (2010) "Ranking the schools: How quality information affects school choice in the Netherlands." IZA discussion paper $n^{\circ} 4984$. Available at: <http://ftp.iza.org/dp4984.pdf >. Accessed on: June, 25 $5^{\text {th }}, 2011$.

MIZALA, A. \& M. URQUIOLA. (2013) "School Markets: The impact of information approximating schools' effectiveness." Journal of Development Economics, 103, 313-335.

WOOLDRIDGE, J. (2001) "Econometric Analysis of Cross Section and Panel Data." Cambridge: The MIT Press, $1^{\text {st }}$ edition.

\section{APPENDIX}

\section{A.1. Results using Local Standardized Multiple Choice Scores (LSMCS) as} school quality proxy 
Table A.1. Local Standardized Multiple Choice Scores (LSMCS) as school quality proxy

\begin{tabular}{|c|c|c|c|c|c|c|}
\hline \multicolumn{7}{|c|}{ Panel A: Ordinary Least Squares Regressions } \\
\hline Variable & $\begin{array}{l}(13) \\
\text { Grade 2: } \\
\text { One- } \\
\text { period }\end{array}$ & $\begin{array}{l}\text { (14) } \\
\text { Grade 2: } \\
\text { Multi- } \\
\text { period }\end{array}$ & $\begin{array}{l}(15) \\
\text { Grade 6: } \\
\text { One- } \\
\text { period }\end{array}$ & $\begin{array}{l}\text { (16) } \\
\text { Grade 6: } \\
\text { Multi- } \\
\text { period }\end{array}$ & $\begin{array}{l}(17) \\
\text { Grade 12: } \\
\text { One- } \\
\text { period }\end{array}$ & $\begin{array}{l}(18) \\
\text { Grade 12: } \\
\text { Multi- } \\
\text { period }\end{array}$ \\
\hline LSMCS & $\begin{array}{l}124.1 * * * \\
(17.04)\end{array}$ & $\begin{array}{l}124.1 * * * \\
(17.09)\end{array}$ & $\begin{array}{l}151.3^{* * *} \\
(22.8)\end{array}$ & $\begin{array}{l}151.3 * * * \\
(22.86)\end{array}$ & $\begin{array}{l}190.5 * * * \\
(21.27)\end{array}$ & $\begin{array}{l}190.5 * * * \\
(21.33)\end{array}$ \\
\hline After 2006_LSMCS & $\begin{array}{l}10.61 \\
(19.68)\end{array}$ & - & $\begin{array}{l}15.59 \\
(26.17)\end{array}$ & - & $\begin{array}{l}23.3 \\
(24.69)\end{array}$ & - \\
\hline 2007_LSMCS & - & $\begin{array}{l}-.759 \\
(23.6)\end{array}$ & - & $\begin{array}{l}-4.143 \\
(31.2)\end{array}$ & - & $\begin{array}{l}.742 \\
(29.62)\end{array}$ \\
\hline 2008_LSMCS & - & $\begin{array}{l}13.48 \\
(22.51)\end{array}$ & - & $\begin{array}{l}19.34 \\
(29.82)\end{array}$ & - & $\begin{array}{l}28.31 \\
(28.13)\end{array}$ \\
\hline 2009_LSMCS & - & $\begin{array}{l}24.42 \\
(28.08)\end{array}$ & - & $\begin{array}{l}40.77 \\
(36.46)\end{array}$ & - & $\begin{array}{l}51.24 \\
(35.65)\end{array}$ \\
\hline Observations & 335 & 335 & 359 & 359 & 369 & 369 \\
\hline R-squared & .429 & .431 & .466 & .470 & .545 & .548 \\
\hline \multicolumn{7}{|c|}{ Panel B: Fixed-Effects Regressions } \\
\hline Variable & $\begin{array}{l}\text { (19) } \\
\text { Grade 2: } \\
\text { One- } \\
\text { period }\end{array}$ & $\begin{array}{l}(20) \\
\text { Grade 2: } \\
\text { Multi- } \\
\text { period }\end{array}$ & $\begin{array}{l}(21) \\
\text { Grade 6: } \\
\text { One- } \\
\text { period }\end{array}$ & $\begin{array}{l}(22) \\
\text { Grade 6: } \\
\text { Multi- } \\
\text { period }\end{array}$ & $\begin{array}{l}(23) \\
\text { Grade 12: } \\
\text { One- } \\
\text { period }\end{array}$ & $\begin{array}{l}(24) \\
\text { Grade 12: } \\
\text { Multi- } \\
\text { period }\end{array}$ \\
\hline LSMCS & $\begin{array}{l}-6.464 \\
(4.848)\end{array}$ & $\begin{array}{l}-6.282 \\
(4.854)\end{array}$ & $\begin{array}{l}-12.20 * * \\
(4.773)\end{array}$ & $\begin{array}{l}-11.82 * * \\
(4.519)\end{array}$ & $\begin{array}{l}-7.043 \\
(7.729)\end{array}$ & $\begin{array}{l}-6.465 \\
(7.661)\end{array}$ \\
\hline After 2006_LSMCS & $\begin{array}{l}5.470 * \\
(2.766)\end{array}$ & - & $\begin{array}{l}12.05^{* * *} \\
(2.588)\end{array}$ & - & $\begin{array}{l}11.02 * * * \\
(4.006)\end{array}$ & - \\
\hline 2007_LSMCS & - & $\begin{array}{l}.266 \\
(2.265)\end{array}$ & - & $\begin{array}{l}3.291 \\
(2.3)\end{array}$ & - & $\begin{array}{l}.356 \\
(3.244)\end{array}$ \\
\hline 2008_LSMCS & - & $\begin{array}{l}4.863 \\
(3.471)\end{array}$ & - & $\begin{array}{l}11.26 * * * \\
(3.298)\end{array}$ & - & $\begin{array}{l}9.664 * * \\
(4.679)\end{array}$ \\
\hline 2009_LSMCS & - & $\begin{array}{l}15.31 * * * \\
(5.303)\end{array}$ & - & $\begin{array}{l}27.04 * * * \\
(4.867)\end{array}$ & - & $\begin{array}{l}29.95 * * * \\
(6.949)\end{array}$ \\
\hline Observations & 335 & 335 & 359 & 359 & 369 & 369 \\
\hline R-squared & .299 & .341 & .317 & .409 & .281 & .363 \\
\hline
\end{tabular}

Notes: (i) Robust standard errors in parentheses. (ii) Symbols $* * *, * *$ and $*$ indicate respectively pvalues, $\mathrm{p}$, such that $\mathrm{p}<.01, \mathrm{p}<.05$, and $\mathrm{p}<.1$. (iii) Time dummies and a constant were added in all models, but their coefficients are not reported here. 


\section{A.2. Selection Bias Test}

In this section, we report the results for the lagged selection indicator test described in the end of section 4 . The lagged selection indicator is a dummy variable and is named as $S$. In the next table, the number of the regression is a reference to regressions columns of table 5, 6, 7 and 8 . We only report the results associated to fixed-effects regressions because those are our main regressions. Selection bias test for the OLS regressions are available upon request. Table A.2 clearly shows that there is no selection bias according to the lagged selection indicator test, because variable $S$ is non-significant in all regressions.

Table A.2. Lagged selection indicator test

\begin{tabular}{llllllll}
\hline Regression & $\boldsymbol{S}$ & Regression & $\boldsymbol{S}$ & Regression & $\boldsymbol{S}$ & Regression & $\boldsymbol{S}$ \\
\hline $\mathbf{( 7 )}$ & 3.608 & $\mathbf{( 1 9 )}$ & 3.612 & $\mathbf{( 3 1 )}$ & 4.287 & $\mathbf{( 4 3 )}$ & 3.794 \\
& $(5.064)$ & & $(5.101)$ & & $(5.002)$ & & $(4.941)$ \\
$\mathbf{( 8 )}$ & 4.484 & $\mathbf{( 2 0 )}$ & 3.780 & $\mathbf{( 3 2})$ & 4.465 & $\mathbf{( 4 4 )}$ & 2.890 \\
& $(4.402)$ & & $(4.535)$ & & $(4.441)$ & & $(5.229)$ \\
$(\mathbf{9})$ & 5.243 & $\mathbf{( 2 1 )}$ & 5.328 & $\mathbf{( 3 3 )}$ & 5.900 & $\mathbf{( 4 5 )}$ & 5.238 \\
& $(4.835)$ & & $(4.828)$ & & $(4.755)$ & & $(4.641)$ \\
$(\mathbf{1 0})$ & 5.261 & $\mathbf{( 2 2 )}$ & 4.142 & $\mathbf{( 3 4 )}$ & 5.29 & $\mathbf{( 4 6 )}$ & 3.800 \\
& $(4.479)$ & & $(4.710)$ & & $(4.397)$ & & $(5.021)$ \\
$(\mathbf{1 1})$ & -.567 & $\mathbf{( 2 3 )}$ & -.414 & $\mathbf{( 3 5 )}$ & .380 & $\mathbf{( 4 7 )}$ & -.798 \\
& $(7.531)$ & & $(7.451)$ & & $(7.386)$ & & $(7.267)$ \\
$(\mathbf{1 2})$ & 1.442 & $\mathbf{( 2 4 )}$ & .462 & $\mathbf{( 3 6 )}$ & 1.569 & $\mathbf{( 4 8 )}$ & -2.149 \\
& $(6.362)$ & & $(6.715)$ & & $(6.527)$ & & $(7.512)$ \\
\hline
\end{tabular}

Notes: (i) Robust standard errors in parentheses. (ii) Symbols ***,** and * indicate respectively p-values, p, such that $\mathrm{p}<.01, \mathrm{p}<.05$, and $\mathrm{p}<.1$. (iii) Time dummies and a constant were added in all models, but their coefficients are not reported here. 